\title{
特発性内胆汁瘻の臨床的検討
}

\begin{tabular}{llllll}
\multicolumn{7}{c}{ 東邦大学外科学第3 3 講座 } \\
武田 & 明芳 & 鈴木 & 茂 & 宅間 & 哲雄 \\
木下 & 雅道 & 清水 & 義金 & 野田 & 良材 \\
桜井 & 貞夫 & 恩田 & 昌邦 & 炭山 & 嘉伸
\end{tabular}

\section{A CLINICAL STUDY OF SPONTANEOUS INTERNAL BILIARY FISTULA}

\author{
Akiyoshi TAKEDA, Shigeru SUZUKI, Tetsuo TAKUMA, \\ Masamichi KINOSHITA, Yoshikane SHIMIZU, Yoshiki NODA, \\ Sadao SAKURAI, Masakuni ONDA and Yoshinobu SUMIYAMA
}

3rd Department of Surgery, Toho University School of Medicine

過去 10 年間に当科において経験した特発性内胆汁瘦症例は 12 例であった。その内訳は胆震十二指腸 癗 : 4 例, 総胆管十二指腸瘦 : 3 例, 胆囊十二指腸一総胆管十二指腸瘦 : 1 例, 胆襄胃瘻 : 1 例, 胆

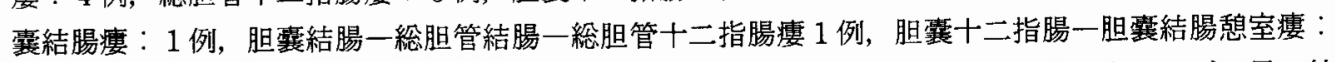
1 例であった。 十二指腸との間に瘦孔を形成した10例では全例術前確定診断可能であったが，胃，結 腸などと瘦孔を形成した 2 例は瘦孔開口部位同定不能であった。術前瘦孔部位不明例でも各種画像診 断で周囲の炎症の波及が予想されて抢り，内胆汁瘻を想定した慎重な手術操作により瘦孔を発見，切 離閉鎖術を施行，場合により腸管部分切除などを付加し良好な予後を得ている。

索引用語：特発性内胆汁瘦

はじめに

特発性内胆汁瘦 (以下, 内胆汁癭) は手術, 外傷な どの外的要因によらず, 胆道系と周囲臓器との間に生 じた異常交通路の総称 ${ }^{1}$ であり, 胆囊と十二指腸との 間に形成されたものが最も多く報告されている2) 4). 内胆汁瘦の診断にあたっては腹部単純 $\mathrm{X}$ 線写真での 胆道内空気像 (pneumobilia) によることが多かった $か^{5)}$ ，近年の各種画像診断法の進歩に上り内胆汁瘦の 術前部位同定も容易となってきている. 当教室で過去 10 年間に経験した特発性内胆汁瘻症例12例につき検討 を加充，文献的考察を加党たので報告する。

$$
\text { 対 象 }
$$

1978年 1 月から1987年 12 月までの過去 10 年間に当教 室において経験した内胆汁瘻の診断に際しては, 瘦孔 の部位が各種検查泉たは開腹手術にて同定されたもの とし, pneumobiliaのみによる瘦孔部位同定不能例は

$<1989$ 年 2 月 15 日受理 $>$ 別刷請求先 : 武田 明芳

$\overline{7} 153$ 目黑区大橋 $2-17-6$ 東邦大学医学部第 3

外科
対象外とした.

結 果

当教室で経験した 12 症例の年齢は44〜71歳にわた り, 平均年㱓は61.7歳, 男女比は $5: 7$ であた（図 1 ).

内胆汁瘻症例の内訳は胆囊十二指腸瘦 : 4 例, 総胆 管十指腸瘦 : 3 例, 胆霊十二指腸一総胆管十二指腸

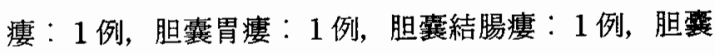
結腸一総胆管結腸一総胆管十二指腸瘦 1 例であり, さ

図 1 性別一年齢別頻度

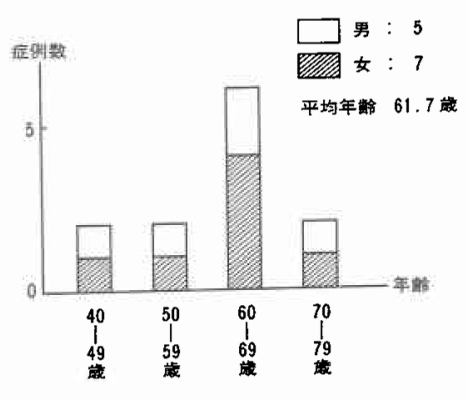


らに現在まで文献的報告のみられていない胆霊十二指

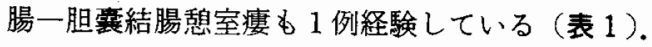

これらは上腹部痛を訴えたもの11例，発熱のみられ たもの 8 例と胆囊炎, 胆管炎症状を持って発症する例 がほとんどであり，黄疾も4例に認められた。臨床症 状を伴わず発見されたのは健康診断目的の上部消化管 造影で発見された症例 No.6のみであった。

病悩期間は無症状例 1 例を含む11例が 4 年以内であ り，10年の長期を経たものは 1 例のみであった。

結石の存在部位は胆変結石 2 例, 胆旁総胆管結石 3 例，胆震肝内胆管結石 1 例，総胆管結石 4 例であり， 症例 No. 2, No. 6以外は有石症例であった。症例 No.

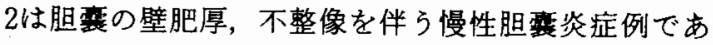
り, 症例 No. 6は傍乳頭部総胆管十二指腸瘦であり, と もに自然排石したすのと思われた

術前診断方法として, 今回腹部単純 X 線写真での peneumobilia の有無, 消化管造影の際の胆道内への造 影剤の流入の有無, endoscopic retrogradecholangiography (以下 ERC) さらに percutaneous transhepatic cholangiography (以下 PTC) での瘻孔描出, 内視鏡

表 1 特発性内胆汁瘻症例

\begin{tabular}{|c|c|c|c|c|c|c|c|c|c|c|c|c|}
\hline \multirow{2}{*}{ 进制 } & \multirow{2}{*}{ 年济 } & \multirow{2}{*}{ 牲制 } & \multirow{2}{*}{ 内車 形式 } & \multirow{2}{*}{ 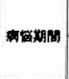 } & \multicolumn{3}{|c|}{ 赫石手在郝位 } & \multicolumn{5}{|c|}{ 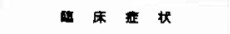 } \\
\hline & & & & & 莇需 & 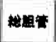 & 开内䀦管 & Wot & 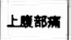 & 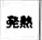 & 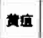 & 下留 \\
\hline 1 & 71 & $F$ & 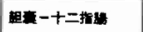 & 6 力月 & $*$ & $*$ & & & * & * & $*$ & \\
\hline 2 & 71 & $M$ & " & 脌 & & & & & , & & & \\
\hline 3 & 44 & M & - & 2 ia & * & * & & & * & * & * & \\
\hline 4 & 66 & $F$ & * & 2 年 & & $*$ & & & * & & & \\
\hline 5 & 68 & M & 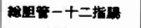 & 3力月 & & * & & & * & * & & \\
\hline 6 & 65 & $\mathbf{F}$ & * & $(-)$ & & & & & & & & \\
\hline 7 & 54 & $F$ & $"$ & 2 力月 & $*$ & & + & $*$ & & & & \\
\hline 8 & 45 & $F$ & 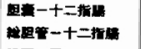 & 了力月 & & * & & & * & $*$ & & \\
\hline 9 & 65 & $F$ & 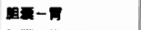 & 2年 & $*$ & & & & * & , & * & \\
\hline 10 & 69 & $M$ & 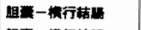 & 2 年 & * & & & & & * & & \\
\hline 11 & 68 & $F$ & 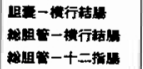 & 3年 & * & * & & & $*$ & $\neq$ & & $*$ \\
\hline 12 & 53 & M & 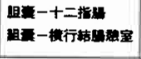 & 10年 & & * & & & * & * & * & \\
\hline
\end{tabular}

表 2 各種検査による術前診断率

施行するる有意な所見を得られなかった症例, *: 内胆汁瘦の存在を疑わしめた症例, $\mathrm{O}:$ 瘦孔の部 位を同定できた症例

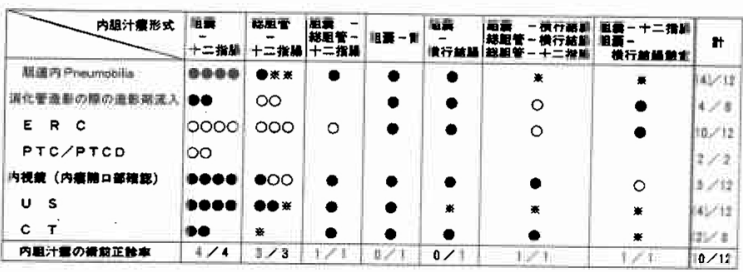

検査による瘦孔開口部位の確認の可否, ultrasonography (以下 US), conputed tomography (以下 CT) で の pneumobilia の有無を検討した（表 2 ).

十二指腸との間に瘦孔を形成した10例では全例瘦孔 開口部位の同定可能であったが，胃，結腸などと瘦孔 を形成した 2 例（症例 No. 9, No. 10）は術前同定不 可能であった。

各診断方法につき検討してみると, 腹部単純 X 線写 真での pneumobilia は総胆管との瘦孔を形成した 5 例中 3 例 $(60 \%)$ にみられたが，全 12 症例中では 4 例 (33\%)にすぎず，もちろん瘦孔部位が同定できるもの ではなかった. US, CT も結石の存在, 胆襄病変の病 態把握には優れるものの, 瘦孔の部位同定は不可能で あり, USでの pneumobilia 描出率は12例中 4 例 (33\%) と腹部単純線写真の検出率と変わらず, CTに おいては 8 例中 2 例（25\%）とより低率であった。

瘦孔の開口部位同定には, ERCのみならず, 黄疸を 呈した症例に行った percutaneous transhepatic cholangiodrainage (以下 PTCD)よりの造影が有用で あり全 12 症例中 10 例（83\%）に值接胆道造影による瘦 孔部位同定が可能であった。この成績に次ぐものは胃 透視, 注腸造影などの消化管造影の際の胆道内造影剂 流入像であり，施行した 8 例中 4 例 (50\%) にみられ た.

しかしながら，このように各種検査を行っても瘦孔 内に結石の嵌頓がみられた症例 No. 9，No. 10では， 術前診断は困難であり, 症例 No. 9は開腹手術時に初 めて内胆汁瘦の存在が確認された。

治療方法として開腹手術を行なったもの6 例, 非手 術的治療法を試みたものが 3 例，経過観察としたもの 3 例であった（表 $3 ） 。$

経過観察とした 3 例の内訳は，症例 No. 2は無石症 例で重篤な心疾患を有していたため保存的治療にて症

表 3 特発性内胆汁瘦症例に対する手術術式の内訳

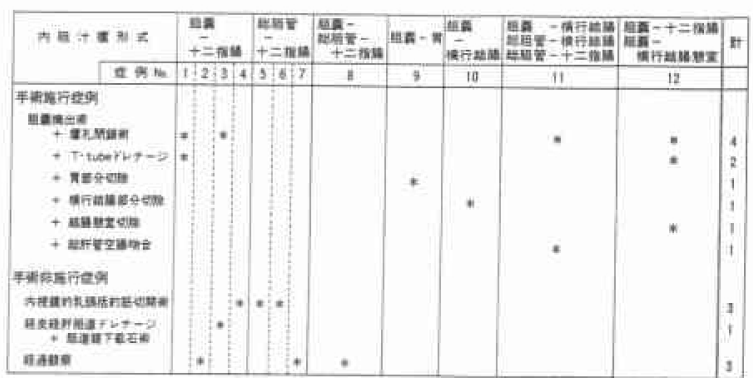


状改善の後経過観察とした。症例 No.7は症状が嘔吐 のみであったため, 症状改善後手術を希望せず経過観 察となった。症例 No.8は ERC にて瘦孔部位確認後肝 機能障害のため手術待機中結石の自然排泄があり, 経 過観察となった。

開腹症例では全例に胆囊摘出術を施行可能であっ た. 付加手術として瘦孔切除に伴ら処置が必要であっ たが，瘦孔部位が確認されていた症例のみならず術前

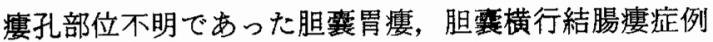
も各種画像診断で胆衰周团への炎症の波及が予想され て扮り, 内胆汁瘦を想定した慎重な手術操作により瘦 孔を発見，切離閉鎖術を括こならことが可能であった。 症例 No. 10, No.12では腸管部分切除, 結腸敀室切除 が必要とされたが, この際も術前に結腸との瘦孔の存 在が予測および確認ができ，充分な術前処置を行い安 全に根治手術を行うことが可能であった。しかし，症 例 No. 11は総胆管と十二指腸, 横行結腸との虑着高度 であり, 総胆管切除, 総肝管空腸吻合を必要とした。 手術症例経過良好であり, endoscopic sphincterotomy （以下 EST）などの保存的療法をおこなった症例を含 め, 症状の改善が得られている。

\section{考 察}

胆道系々周囲他臟器との間に異常瘦孔を形成する内 胆汁漊のなかです外傷，手術などの外的要因によらぬ ものが特発性内胆汁瘦之定義されている11. その成因 に関与するものとして, 十二指晹潰瘍 ${ }^{7)}$, 悪性疾患 ${ }^{8}$, 急性膵炎 ${ }^{4)}$, 肝膿瘍(4)さに先天的に形成された胆囊管 十二指腸瘐の 1 (例) む報告されているが，胆道結石に 起因するものが83 91\% ${ }^{344) 10)}$ と大勢を占めている.

当教室の症例は 12 例中 10 例が有結石症例であり, 他 の 2 例も消化性潰癔などの合併疾患はなく, 胆道疾患 の病態から判断すると自然排石症例の可能性が高く, 全例が胆道疾患に基づくものと考光られ，内胆汁瘦の 形成に結石の存在が大きな役割を占めるるのと思われ た. その中で症例 No. 12は胆囊十二指腸一胆囊横行結 腸想室との二重瘦孔形成例であったが, 結腸鄎室との 瘦孔形成には䅣室炎の波及による瘦孔形成の可能性む 否定はできなかったが，胆囊よりの炎症波及と考元る のが妥当であろう。

胆石による内胆汁瘻形成機序に関して, 胆囊瘦の場 合は acute obstructive cholecystitis の増悪により胆 襄内圧が上昇, 高度の炎症性循環障害から壁の変性壊 死をきたし，近接する腸管が炎症性変化を起こし胆囊 に虑着した部に胆道腸管瘦を形成すると考えられてい
$3^{5) 11)}$. 総胆管十二指腸㾇の成因に関しても, 傍乳頭部 総胆管十二指腸㿉については十二指腸後壁穿通性潰瘍

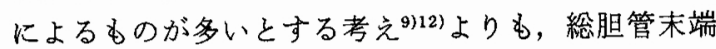
部の結石により胆管に炎症を起こし，十二指腸壁に炎 症が波及する結果その部に壊死をきたし，さらに胆管 内圧の上昇により結石が十二指腸内に脱出，瘦孔を形 成すると考光られている ${ }^{13)}$.

症例 No. 8 は当科入院時は総胆管内に結石を認める も十二指腸との間に瘦孔は存在せず，入院経過中に結 石の排泄, 傍乳頭部総胆管十二指腸凄の形成をみた例 であり，この考劣を裏付けるるのであった。

結石の存在部位としては，われわれの検討した中で は総胆管内に結石を認めた症例が12例中 7 例 (58\%) と他家の報告3144)同樣高率であった。

瘦孔形成部位は自験例についてみると, 胆垔十二指 腸瘦 12 例中 6 例 $(50 \%)$, 総胆管十二指腸瘦 12 例中 5 例 $(42 \%)$, 胆輁横行結腸瘻 2 例, 胆震胃瘦, 総胆管横行

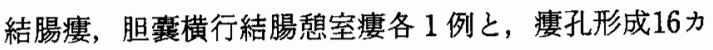
所中十二指腸との瘦孔が11例 (69\%) と過半数を占め た。福永ら 3 は欧米報告例540例，本邦報告例195例を集 計し, 胆囊十二指腸瘦は前者で $68 \%$, 後者で $61 \%$ と自 験例よりやや高い値を報告しているが，総胆管十二指 腸瘦はそれぞれ $9 \%$, 11\%と少なく自験例との差が大き い.

この点については，近年の上部消化管内視鏡検査お よび直接胆管造影の発達普及, 手技の向上が診断能の 向上をるたらしたものと思われる4．

内胆状瘦の存在診断には, 胆管内の空気像 (pneumobilia) の描出による事が多い15). 腹部単純 X 線写真に頼っていた pneumobilia 像す US, CTでの 描出が可能となり, 内胆汁㾇発見の機会が増加したの であろう。しかし，本来ならば微量の空気の描出にも 優れているはずのCTでも pneumobilia 描出率は腹 部単純 X 線写真よりも低く，25\%にみられたのみで あった。

症例 No. 11では腹部単純 X 線写真で確認された pneumobiliaが CT では検出されなかった。これは立 位にて撮影されるX線写真や，自由に体位変換可能な US に比べ，体位の制限を受けるCTの難点と思われ た. US 像と空気量の多夏により異なる像を呈し, 高田 ら ${ }^{16)}$ は branching type と stair type に大別している。 体位変換の際の胆管像の変化に留意すべきであろう。

瘦孔の部位診断として, 自験例では ERC, PTCD よ りの造影の有用性が高く, 全12症例中 $83 \%$ に瘦孔部位 
同定が可能であった. 本邦集計例3)では ERCでの正診 率が施行 17 例中 3 例 (18\%) と低かったが, 器具の改 良，手技の習熟による改善と思われる。このような高 い正診率を得られる ERC, PTC/PTCD 造影も, 病態 把握としての精密検査としての役割が尃らであり,内 胆汁瘻の存在を示唆するといら点で X 線写真, 消化管 造影検査, そして今や外来にも常置されるようになっ てきたUSの占める位置は大きい。

内胆汁瘻の治療方針では, 胆管炎症状がなければ上 部消化管との交通は，そのまま放置して差し支えな い11) と考学られているが，本邦症例に占める結石保有 率の高さや，自験例にみるごとき症状発現率の高さか らも, 早期の治療が必要となることが多い，基礎疾患 としての胆桽結石, 総胆管結石に対する治療が重要で あるが，今日では外科的治療のみならず, ESTや PTCD よりの内視鏡下截石術も有効な手技之なって おり, 今回の症例です 3 例に ESTを, 1 例に内視鏡下 截石術を行った. ERCの発達普及により発見されるこ とが增えてきたと思われる旁乳頭部総胆管十二指腸瘦 に対しては非手術的にESTを扔こない, 症状の改善 を得ている。手術療法としては, 胆要摘出術, 瘦孔切 除術に加えるに, 穿通脸器の修復も必要となってくる. 多くの場合は瘦孔閉鎖術が行われるが, 症例 No.10で は资症による高度の療着のため腸管部分切除が行われ た。このような胆道結腸瘦では, 手術時の腸管の解放 と胆道炎の合併のため敗血症の危険があり, 結腸切除 之同様の術前処置が必要である3が，各種画像診断に より瘦孔の存在が予測できることにより，充分な術前 処置が可能となっている.

基礎疾患としての胆裹結石, 総胆管結石に対する治 療が重要であるが, ERCの発達普及により発見される ことが增えてきたと思われる旁乳頭部総胆管十二指腸 瘦に対しては非手術的にESTを行い, 症状の改善を 得ている. 胆道系の炎症高度の場合には総胆管外瘦の みでは, 再手術が余儀なくされた報告4すあり, 症例 No.11のような胆道再建も考慮されるべきであろう.

\section{結 語}

当教室に扔いて経験した特発性内胆汁瘦症例12例に つき, 病態, 診断方法, 治療法など, 種々の点につい て検討し，文献的考察を加光報告した。

腹部単純 X 線写真, US, CT は内胆汁瘦の存在を示 唆するには有効であったが, 瘻孔の部位同定は困難で

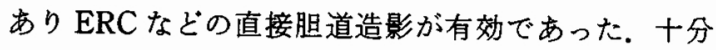

な術前検查を行い瘦孔の部位同定に努めることが良好 な予後を得るためには重要であると思われた。

なお, 本論文の要旨は第32回日本消化器外科学会総会に て発表した。

1）高田忠敬：内胆汁瘻. Medicina $13: 234-235$, 1976

2) Glenn F, Reed C, Grafe WR: Biliary enteric fistula. Surg Gynecol Obstet 153:527-531, 1981

3）福永裕充，青木洋三, 勝見正治注加：特発性内胆汁 瘦一自鵌例23例を含めた本邦症例の集計と文献的 考察一。日臨外医会誌 $43: 173-182,1982$

4）票島恭彦, 内村正幸, 武藤良弘任：胆石による内 胆计瘦形成例の検討. 日臨外医会誌 $43: 960-$ 966,1982

5）䚗島恭彦, 内村正幸, 武藤良弘ほか：胆石症の加龄 にともなら臨床像の变化. 日臨外医会誌 38 ： $810-817,1977$

6) 平林秀三, 横山新一郎, 水上忠弘湶か：慢性下浰を 主訴とした胆衰結腸㾇の 1 例。昭和医会誌 43 ： 415-419, 1983

7) Constant E, Turcotte JG: Choledochoduodenal fistula: The natural history and management of an unusual complication of peptic ulcer disease. Ann Surg $167: 220-228,1968$

8）藤原庸隆，伊藤克昭，春日井達造：胆衰横行結腸瘦 を形成した胆衰癌の 1 例。胆之脺 $5: 1701$ 1704, 1984

9）梅本敬夫, 石川 享, 㠇見靖彦ほか：総胆管捘張症 に合併した先天性胆震管十二指腸凄の 1 治験例。

日臨外医会誌 $49: 88-92,1988$

10) Glenn F, Mannix H: Biliary enteric fistula. Surg Gynecol Obstet 105:693-705, 1957

11）杉浦光雄著：肝臓・胆道 II 機構ならびに機能異 常. 木本誠二監修. 現代外科学大系. $38 \mathrm{~B}$, 中山書 店, 東京, 1971，p219-227

12) Hutchings VZ, Wheeler JR, Puestow $C B$ : Choledochoduodenal fistula complicating duodenal ulcer: A report of five cases and review of the literature. Arch Surg $75: 598-$ 605, 1956

13）内山勝弘, 高田忠敬, 安田秀喜: 総胆管十二指腸瘦 が診断の契機となった肝内結石症の 2 例。日臨外 医会誌 $45 ： 648-653 ， 1984$

14) Epperson DP, Walters $W$ : Spontaneous internal biliary fistulas. Mayo Clin Proc 28 : 353360,1953

15) Domke HH: Zur Diagnose innerer Gallenfisteln. Fortschr Rontgenstr $94: 608-618,1961$

16）高田忠敬, 安田秀喜, 内山勝弘：Pneumobilia の超 音波診断に関する検討一基礎的ならびに臨床的検 討一。消外会誌 $17 ： 1416-1420,1984$ 